Code Green 
A volume in the series The Culture and Politics of Health Care Work

edited by Suzanne Gordon and Sioban Nelson

Nobody's Home: Candid Reflections of a Nursing Home Aide by Thomas Edward Gass 


\section{Code Green}

Money-Driven Hospitals and the Dismantling of Nursing

\section{Dana Beth Weinberg}

Foreword by Suzanne Gordon

ILR Press an imprint of

Cornell University Press

Ithaca and London 


\section{Copyright (C) 2003 by Cornell University}

All rights reserved. Except for brief quotations in a review, this book, or parts thereof, must not be reproduced in any form without permission in writing from the publisher. For information, address Cornell University Press, Sage House, 5 I 2 East State Street, Ithaca, New York I 4850.

First published 2003 by Cornell University Press

First printing, Cornell Paperbacks, 2004

Printed in the United States of America

Library of Congress Cataloging-in-Publication Data

Weinberg, Dana Beth.

Code green : money-driven hospitals and the dismantling of nursing / Dana Beth Weinberg; foreword by Suzanne Gordon.

$$
\text { p. cm. }
$$

Includes bibliographical references and index.

ISBN-I 3: 978-0-80I4-3980-3 (cloth : alk. paper)

ISBN-IO: O-80I4-3980-9 (cloth : alk. paper)

ISBN-I 3: 978-0-80I4-89I9-8 (pbk. : alk. paper)

ISBN-IO: O-80I4-89I9-9 (pbk. : alk. paper)

I. Nursing-Massachusetts-Boston. 2. Beth Israel Deaconess Hospital CenterFinance. 3. Hospitals-Massachusetts-Boston-Finance. I. Title.

$$
\begin{aligned}
& \mathrm{RT}_{5} \cdot \mathrm{M}_{4} \mathrm{~W}_{45}{ }_{2003} \\
& \text { 6I0.73'09744'6I-dc2 I }
\end{aligned}
$$

Cornell University Press strives to use environmentally responsible suppliers and materials to the fullest extent possible in the publishing of its books. Such materials include vegetable-based, low-VOC inks and acid-free papers that are recycled, totally chlorine-free, or partly composed of nonwood fibers. For further information, visit our website at www.cornellpress.cornell.edu.

Cloth printing

Paperback printing
I0 $98 \begin{array}{lllllll} & 7 & 6 & 5 & 4 & 3 & 2\end{array}$

I0 $98 \begin{array}{llll} & 8 & 6 & 5\end{array}$ 
to my parents, Glenda and Alan Weinberg,

and

to the nurses, for the care they want to give 
